FINAL REPORT

T0

THE SOLAR ENERGY RESEARCH INSTITUTE

on

Sub-Contract XK-4-04136-04

R. E. Cooksey, Principal Investigator

Department of Microbiology, Montana State University

Bozeman, MT 59717

May 1987 
CONTENTS

Page

Abstract . . . . . . . . . . . . . . . . . . . . 1

Introduction .......................... 1

Rationale for the Research Approach . . . . . . . . . . . . 2

Task I Collection .................... 2

Task II Determine Lipid Content . . . . . . . . . . . 2

Task III Development of Flow Cytometric and Other Quantitative

Methods for Lipid Analysis . . . . . . . . . . 2

Task IV A Radiotracer Method for Lipid Production Screening of Microalgal Cells . . . . . . . . . . . . 2

Materials and Methods . . . . . . . . . . . . . . . 2

A. Isolation of Thermotolerant Diatoms . . . . . . . . 2

B. Determination of Dry Weight and Ash-Free Dry Weight . . . . 3

C. Determination of Lipid .................. 3

D. Chlorophyll a Determinations .............. 4

E. Nitrate Determination ................ 4

F. Growth Measurements .................... 4

G. Nile Red Staining ..................... 4

H. Flow Cytometry ...................... 4

I. Spectrofluorometry ................. . 5

J. Microscopy . . . . . . . . . . . . . . . . . 5

K. Lipid Characterization . . . . . . . . . . . . . . 5

L. Experiments to Correlate Nile Red Staining with a Particular Lipid Fraction................... 5

(Detalls of some of these methods are also found in Appendix.)

Results :. . . . . . . . . . . . . . . . . . 5

Collecting Sites ..................... 5

Growth of Isolated Diatoms . . . . . . . . . . . . . 7

Fluorometric Determination of Lipid Using the Dye, Nile Red . . 8

Discussion . . . . . . . . . . . . . . . . . . 11

Task I Collection and Isolation of Strains . . . . . . . . 11

Task II Determination of Lipid Content of Ten Algal Strains . . 11

Task III Development of Flow Cytometry and Other Fluorescence Techniques to Determine Lipid Content of Algal Cells . . 12

Task IV Development of a Radiotracer Assay for Lipid

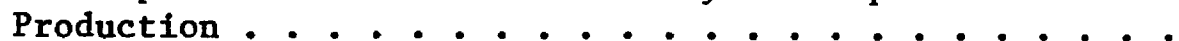


References ..........................

Acknowledgements . . . . . . . . . . . . . . . . 14

Publications and Presentations Resulting from Contract XK-4-04136-04 .

Table 1 Diatoms Isolated from Yellowstone Park and Selected from Existing Collection on Basis of Microscopically Identified Lipid Inclusions . . . . . . . . . . . . . . . . 6

2 Lipid Production by Selected Diatoms at $35^{\circ} \mathrm{C}$. . . . . . . 7

3 Growth of Selected Diatoms in SERI Type I Medium . . . . . . . 8

4 Growth of A. coffeaeformis and Nile Red Staining . . . . . . 9

Figure 1 .......................... 10

Appendix: Fluorometric Determination of the Neutral Lipid Content of Microalgal Cells Using Nile Red. Submitted to Journal of Microbiological Methods. 


\title{
COLLECTION AND SCREENING OF MICROALGAE FOR LIPID PRODUCTION
}

\author{
K. E. Cooksey \\ Department of Microbiology, \\ Montana State University, Bozeman, MT 59717
}

$\underline{\text { Abstract }}$

Thermotolerant microalgae were selected from an existing culture collection and isolated from hot spring areas of Yellowstone National Park. Several of them grew at $35^{\circ} \mathrm{C}$, although only one grew at much better than 1 doubling per day. All were diatoms which produced $12-57 \%$ of their dry weight as Bligh-Dyer extractable total lipid. We have found that a vital fluoro-

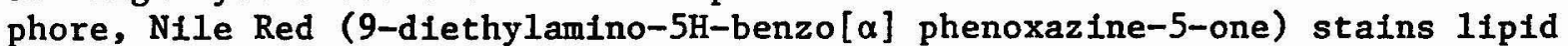
inclusion and can be used to determine neutral lipid. The method also allows mixed algal cultures to be screened for lipid production.

Introduction

The energy crisis in 1973 brought home to many people the fact that the world's supply of oil was not unlimited. Since that time there have been various attempts to investigate other sources of energy and many of these have centered on the use of solar energy in one form or another. A particular example is the production of fuel-grade ofl from microalgal biomass. The project being investigated by the Solar Energy Research Institute Involves the growth of specific oleaginous microalgae in brackish water ponds in the southwest deserts of the U.S.A. The algae used in this process need certain physiological characteristics in order for the project to be viable. It is self-evident that any algae used must have a high lipid production rate. Because of the high daytime temperatures and light intensities in a desert climate, algae must also grow well in these conditions since control of these environmental parameters cannot be achieved in a cost-effective manner. One of the objectives of this project, therefore, concerns the isolation of thermotolerant microalgae able to grow at high light intensities. A second objective concerns a means of selection of algal strains that produce large quantities of neutral 1ipids. For the purposes of this work, neutral lipid is defined as the triacylglyceride and hydrocarbon fraction of the cell. Since neither of these groups of compounds have functional groups that are easy to assay chemically, lipid is usually determined gravimetrically after non-polar solvent extraction of the algal cells (1). A method for the in situ analysis of neutral lipid would prove extremely useful in this research, as would means of selection of high-yielding strains produced by mutation or protoplast fusion. This second objective, therefore, concerned the development of an assay for neutral lipid using intact cells and the separation of high lipidcontaining cells from a heterogeneous population. 
Rationale for the Research Approach

\section{Task I: Collection}

To find thermotolerant algae that grow at $35^{\circ} \mathrm{C}$, we have sampled hot springs in Yellowstone National park, since these algae are subjected naturally to elevated thermal gradients. All isolations from natural material were made at $35^{\circ} \mathrm{C}$.

Task II: Determine lipid content

Analytical procedures already common in the Aquatic Species Program of SERI were to be used.

Task III: Development of flow cytometric and other quantitative methods for lipid analysis

The analytical procedures referred to in Task II depend on the aval1ability of $0.5-1.0 \mathrm{~g}$ (wet weight) quantities of microalgal cells to be produced from at least unialgal, if not axenic, cultures. The emphasis under Task II was to develop alternate methods which did not use a lipid extraction procedure, were more sensitive than the gravimetric procedure and, if possible, could be used to select viable high lipid producing cells from mixtures.

Task IV: A radiotracer method for lipid production screening of microalgal cells

This procedure was to be developed as an alternate method to that mentioned under Task III. From previous work $(2,3)$ we knew that $14 \mathrm{C}$-acetate incorporation into whole algal cells in the light went largely into the lipid fraction of the cell. This was to have been extracted and compared to total acetate incorporation as a measure of relative cellular lipid. Since the methodology developed under Task III proved so successful, we were advised to concentrate on making the Nile Red method publishable in the open literature, since the 14-C method, although potentially sensitive, required the use of axenic cultures and an extraction step.

Materials and Methods

These are not separated by task designation, since most methods are common to each task.

A. Isolation of Thermotolerant Diatoms

1. Culture Method. Samples of algae were collected from various thermal areas in Yellowstone Park. Collection data included temperature, $\mathrm{pH}$, and, where possible, conductivity ( $\mu$ mhos). All samples were examined microscopically and those containing microalgae were transferred as follows: $0.5 \mathrm{ml}$ cell suspension into $5 \mathrm{ml}$ of medium in $15 \mathrm{ml}$ screwcapped culture tube; $1.0 \mathrm{ml}$ into $25 \mathrm{ml}$ of media in $125 \mathrm{ml}$ culture flask. Cultures were incubated at $35^{\circ} \mathrm{C}$ and examined daily for growth. As growth occurred, algae were streaked onto agar (2\%) plates of 
appropriate media. Cells or colonies growing on agar were picked and transferred to tubes of media $(1 \mathrm{ml})$. As growth occurred in $1 \mathrm{ml}$, transfer was made into $5 \mathrm{ml}$. When growth occurred in $5 \mathrm{ml}$, a bacterial contamination check was made. The test medium was $0.05 \%$ yeast and $0.05 \%$ glucose in the mineral salts algal medium. If bacteria were present, algae were streaked onto antiblotic agar plates. These were made from $0.3 \%$ penicillin $G$ and $0.5 \%$ streptomycin sulfate, in distilled $\mathrm{H}_{2} \mathrm{O}$. This solution was filter-sterilized and stored frozen. For use, $1.0 \mathrm{ml}$ was added to $100 \mathrm{ml}$ agar. media. Colonles or cells were picked again, grown, and re-tested for bacterla. Axenic cultures were maintained on appropriate media in agar-slant tubes at $35^{\circ} \mathrm{C}$. Transfers were made every 3-4 weeks into fresh media and test media tubes to check for the presence of bacteria. When the Nile Red fluorescent staining procedure had been developed, we stained both collected material and crude mixed enrichments for the presence of lipid droplets. Where none were seen, the biological material was discarded.

2. Media Used. Inftially, three culture media were used - SERI Type I, SERI Type II (both at 25 mmos $\mathrm{cm}^{-1}$ ), and ASP210. After isolating the current strains, only ASP $_{2} 10$ (4) and SERI Type I were used. A1l strains grew in ASP 210 . Not all of the new strains grew in SERI I; none grew in SERI II. One litre of SERI Type I water (' 25 mmos) (5) was enriched as follows: $8 \mathrm{mg} \mathrm{KH} 2 \mathrm{PO}_{4}, 1 \mathrm{mg} \mathrm{Na} \mathrm{SiO}_{3} \cdot 9 \mathrm{H}_{2} \mathrm{O}, 42 \mathrm{mg} \mathrm{NaNO}$, $5 \mathrm{ml}$ trace metal solution (6), $1 \mathrm{ml}$ vitamin mixture (6). $168 \mathrm{mg}$ $\mathrm{NaHCO}_{3}$ in $10 \mathrm{~m} 1$ water was added aseptically to $990 \mathrm{ml}$ sterile basal medium.

B. Determination of Dry Weight and Ash Free Dry Welght

Filters (Whatman GFA, $2.4 \mathrm{~cm}$ ) were rinsed three times with distilled water $(20 \mathrm{ml})$, dried, placed in numbered aluminum boats and pre-combusted at $500^{\circ} \mathrm{C}$ for 2 hours. Three $50 \mathrm{ml}$ aliquots of cell culture were filtered onto pre-welghed, pre-combusted filters and rinsed with $5 \mathrm{ml}$ culture medium. A blank consisted of a $50 \mathrm{ml}$ aliquot of media ( $1 . e$. , no cells) filtered onto an appropriate filter. All filters were air dried, replaced in appropriate aluminum boats and dried at $90^{\circ} \mathrm{C}$ to constant weight. Dry welght of the cells was corrected for the medium blank. To determine ash, the filters were combusted at $500^{\circ} \mathrm{C}$ until constant weight was achieved. This value was used to correct the dry weight values. The mean of 3 values is reported. With some of the smaller cells, larger volumes of culture were required.

C. Determination of Lipid

Fifty $m l$ of culture was filtered as described for the dry weight determination. Two such filters with cells were extracted by the method of Bligh and Dyer (7) (see also Ben-Amotz, 8) at the same time in a sealed tube. Extractions, which were performed in triplicate, were carried out successively for $12 \mathrm{hr}, 2 \mathrm{hr}$, and $1 \mathrm{hr}$. After phase separation, the chloroform layers were removed, combined and made to $10 \mathrm{ml}$. After filtration through a glass-fibre filter, $9 \mathrm{ml}$ of the lipid extract was dried to constant weight in a pre-weighed aluminum boat. Lipid values are reported as the mean of three determinations corrected for chlorophyll. 
The chlorophyll correction was less than $8 \%$ by weight of the total chloroform-methanol extractable lipid. Later experiments (see Appendix) utilized a modification of this method. The extraction was performed overnight in separatory funnels rather than test tubes. Cells from $200 \mathrm{ml}$ culture were placed in separatory funnels containing $37.5 \mathrm{ml}$ methanol, $18.75 \mathrm{ml}$ chloroform and $15 \mathrm{ml}$ water. This represents a one-phase extraction. After approximately 12 hours at room temperature $18.75 \mathrm{ml}$ chloroform and $18.75 \mathrm{ml}$ water were added. The chloroform phase separated out and was decanted. The sample after concentration by evaporation, was applied to preweighed $13 \mathrm{~mm}$ fibre-glass pre-filters (Mililpore Corp.) and lipid calculated from the increase in weight after drying. This procedure proved more conventent and sensitive than the method using an aluminum boat.

D. Chlorophyll a Determinations

These were made fluorometrically on $90 \%$ acetone extracts of filtered cells (9). Chlorophyll was determined from the fluorescence values corrected for the presence of phaeophytin. A standard curve was prepared using pure chlorophyll a.

E. Nitrate Determination

Cells were removed from medium by filtration and nitrate determined by the cadmium column reduction method (10). In later experiments the commercially available reagent system developed by Hach Inc. was used.

F. Growth Measurements

Cel1 counts were made using a haemocytometer. Late logarithmic phase cells were used to inoculate fresh medium at an initial cell count of 50,000 cells $\mathrm{ml}^{-1}$. Cell inocula were checked for the presence of bacteria by Inoculating a sample into yeast extract/glucose medium. No growth of bacteria in the enriched medium was considered evidence for the axenic nature of the inoculum.

G. Nile Red Staining

Stock solutions of Nile Red ( $250 \mu \mathrm{g} \mathrm{m1-1}$, Molecular Probes, Oregon; Kodak, Rochester, N.Y.), were made in acetone and stored at $4^{\circ} \mathrm{C}$ in the dark. Cell suspensions (about $10^{6} \mathrm{ml}^{-1}$ ) were stained with final dye concentrations ranging from 0.01 to $10 \mu \mathrm{gl}^{-1}$ and for various times. Optimal staining time and dye concentrations were investigated using the flow cytometer, a spectro- fluorometer, or a filter fluorometer. In some experiments cells were fixed in $70 \%(\mathrm{v} / \mathrm{v})$ ethanol or $4 \%(\mathrm{w} / \mathrm{v})$ formaldehyde for $15 \mathrm{~min}$. and resuspended in minimal medium for staining and flowcytometric analysis.

H. Flow Cytometry

We have used a Becton-Dickinson FACS 440 equipped with a Spectra-Physics 164-02 argon ton laser. Diatoms in ASP-2 medium containing $0.25 \mathrm{mM} \mathrm{Ca}$ (4), either stained or unstained, were passed through the instrument using a diluent of minimal medium (9) containing $0.25 \mathrm{mM} \mathrm{Ca}$. The over pressures 
in the liquid containers were 14 psi (diatom suspension) and 17 psi (sheath fluid). It was important to agitate the diatom suspension from time to time and to pre-treat the suspension with ultrasound to break up clumps, especially after the cells had been centrifuged. A sortingaperture of $70 \mu \mathrm{m}$ was used for diatom cells of approximately $20 \mu \mathrm{m}$ in length. Unstained cells could be excited at $488 \mathrm{~nm}(100 \mathrm{~mW})$ and examined by means of their fluorescence at $530 \pm 15 \mathrm{~nm}$ (green) in conjunction with a dichroic mirror at $560 \mathrm{~nm}$. This autofluorescence was not due to chlorophyll a which emits in the red region of the spectrum. Using a bandpass filter at $575 \pm 15 \mathrm{~nm}$ allowed the fluorescence of Nile red-stained cells to be examined without interference from green or red autofluorescence. Results are expressed as number of events ( $y$-axis) versus the logarithm of the fluorescence intensity of an individual cell ( $x$-axis). Instrumental alignment adjustments were made daily and were based on the fluorescence of $2.8 \mathrm{~mm}$ Nile Red-stained latex particles (Pandex Corporation, Mundelein, Illinois).

\section{Spectrofluorometry}

Two instruments were used. For kinetic experiments and those requiring the use of specific wavelength, we used a Spex Fluorolog Model F211 spectrofluorometer equipped with a $150 \mathrm{~W}$ Xenon lamp. To compare the relative lipid content of various cultures (e.g., Table 3, Appendix), we used a Turner Model 10 filter fluorometer. Details of the methods can be found in the Appendix.

\section{J. Microscopy}

See Appendix.

K. Lipid Characterization

The methods for the separation of lipids into major classes and their gas chromatographic/mass spectrometric analyses are detailed in the Appendix.

L. Experiments to Correlate Nile Red Staining with a Particular Lipid Fraction

These are in the Appendix.

$\underline{\text { Results }}$

Collecting Sites

These were all in Yellowstone National Park. We found the background information in the park from Brock (11) and from the park scientific staff to be very helpful in selecting sites for diatom collection. Environments sampled ranged from $\mathrm{pH}$ 2.7-8.5, conductivity from 389-1051 $\mu$ mhos, and temperatures from $35^{\circ}-60^{\circ} \mathrm{C}$ (Table 1). Diatoms were observed at all sites, but we could not say anything concerning their viability. Table 1 gives the sites from which cultures were obtained. Other sites visited included Roaring Mountain ( $\left.\mathrm{pH} 2.3,35^{\circ} \mathrm{C}\right)$, Grand Prismatic Spring ( $\mathrm{pH} 8.0 ; 35^{\circ}-58^{\circ} \mathrm{C}$ ), and other unnamed springs ( $\left.\mathrm{pH} 2.0-6.5 ; 35-61^{\circ} \mathrm{C}\right)$. 
Table 1. Diatoms Isolated from Yellowstone Park and Selected from Existing Collection on Basis of Microscopically Identified Lipid Inclusions.

\begin{tabular}{|c|c|c|c|c|c|}
\hline \multirow[b]{2}{*}{$\begin{array}{l}\text { MSU Strain } \\
\text { Identification }^{a}\end{array}$} & \multicolumn{4}{|l|}{ Details of Site } & \multirow[b]{2}{*}{$\begin{array}{c}\text { Successful } \\
\text { Media }\end{array}$} \\
\hline & Site & $\begin{array}{l}\text { Temp } \\
\left({ }^{\circ} \mathrm{C}\right)\end{array}$ & $\begin{array}{l}\text { Cond 'y } \\
\text { ( } \mu \text { mhos) }\end{array}$ & $\mathrm{pH}$ & \\
\hline SERI 1 & Nymph Lake Inlet, YNP & 38 & - & 2.7 & $1^{b}, 2^{c}$ \\
\hline SERI 2 & Gibbon $R$. vents, YNP & 33 & 389 & 6.6 & 1 \\
\hline SERI 3 & Beryl Spring, YNP & 33 & 963 & 7.8 & 1 \\
\hline SERI 4 & Firehole R., YNP & 36 & 1051 & 8.5 & 1,2 \\
\hline SERI $5 a$ & Firehole R., YNP & 36 & 1051 & 8.5 & 1,2 \\
\hline SERI $5 b$ & 0jo Caliente Spring, YNP & 36 & 1051 & 8.5 & 1,2 \\
\hline SERI 6 & Biscayne Bay, Fla. & 28 & -- & 8.2 & 1,2 \\
\hline SERI 7 & Biscayne Bay, Fla. & 28 & -- & 8.2 & 1,2 \\
\hline SERI 8 & C1earwater Spring, YNP & $35-60$ & -- & 3.5 & 1,2 \\
\hline SERI 9 & Obsidian $\mathrm{Cr}$. , YNP & 35 & -- & 2.3 & 1,2 \\
\hline SERI 10 & Biscayne Bay, F1a. & 28 & -- & 8.2 & 1,2 \\
\hline SERI 11 & Biscayne Bay, Fla. & 28 & -- & 8.2 & 1,2 \\
\hline SERI 12 & Bahama Banks & 28 & -- & 8.2 & 1,2 \\
\hline SERI 13 & Card Sound, Fla. & 28 & -- & 8.2 & 1,2 \\
\hline SERI 14 & Big Soda Lake, Nev. & -- & - & 9.5 & 1 \\
\hline SERI 15 & Sa1t Marsh, Long Is., N.Y. & & - & - & 1 \\
\hline SERI 16 & Salt Marsh, Long Is., N.Y. & & -- & -- & 1 \\
\hline
\end{tabular}

a All organisms are diatoms.

$\mathrm{b}_{1}=\mathrm{ASP}_{2}-10$, See ref. 4 .

c 2 = SERI Medium I 25 mmhos $\mathrm{cm}^{-1}$, no figure ' 1 'or ' 2 implies no detectable growth in this medium. 


\section{Culture Collection}

Most cultures tested were isolated from southern Florida and the Bahamas in the mid-1970's. Three were isolated by others or from samples provided by others. Twenty isolates were screened for growth at $35^{\circ} \mathrm{C}$ and 1 ipid production as shown by Nile Red staining. Six cultures were selected for further study from only nine that grew at $35^{\circ} \mathrm{C}$. This suggests that $28^{\circ} \mathrm{C}$, the temperature of isolation for the marine isolates, was already close to the maximal growth temperature. Table 2 gives the lipid accumulation, cell yield and divisions per day for these cultures as well as those isolated from thermal springs.

Few strains grew well at $35^{\circ} \mathrm{C}$. Since Amphora IIIB (SERI 13) produced particularly obvious lipid droplets, it was grown at its optimal temperature of $28^{\circ}$, since we found it grew hardly at all at $35^{\circ} \mathrm{C}$.

Table 2. Lipid Production by Selected Diatoms at $35^{\circ} \mathrm{C}$.

\begin{tabular}{lcccc}
\hline Strain & $\begin{array}{c}\text { Mell No. } \\
\times 10^{-6} 1^{-1}\end{array}$ & $\begin{array}{c}\text { Mrowth Rate } \\
\text { day }\end{array}$ & $\begin{array}{c}\text { AFDW } \\
\text { mg }\end{array}$ & $\begin{array}{c}\text { Lipid } \\
\%\end{array}$ \\
\hline SERI 2 & 1.25 & 0.83 & 125 & 53.7 \\
SERI 3 & 0.5 & 0.85 & 47 & 9.6 \\
SERI 5a & 6.6 & 1.33 & 78 & 34.7 \\
SERI 5b & 4.0 & 0.95 & 71 & 20.7 \\
SERI 6 & 2.2 & 1.54 & 17 & 31.1 \\
SERI 7 & 2.2 & 1.05 & 30 & 57.1 \\
SERI 8 & 0.6 & 0.86 & 21 & 20.0 \\
SERI 9 & 0.8 & 0.71 & 29 & 12.5 \\
SERI 10 & 0.82 & 0.61 & 19 & 18.3 \\
SERI 13 & 1.0 & 2.0 & 87 & $31.0^{b}$ \\
\hline
\end{tabular}

a Total ash-free dry weight at stationary phase ( 4 to 7 days).

b Grown at $28^{\circ} \mathrm{C}$, all others at $35^{\circ} \mathrm{C}$. $16 / 8 \mathrm{hr}$ light/dark cycle and $100 \mu \mathrm{E} \mathrm{m}-2$ $\sec ^{-1}$. 
Few diatoms grew well in SERI I medium (Table 3). In fact, only one organism (SERI 6) grew at better than one doubling per day. SERI 6 is a small Navicula sp.

Table 3. Growth of Selected Diatoms in SERI Type I Medium.

\begin{tabular}{lcc}
\hline Strain & $\begin{array}{c}\text { Maximal Cell Number } \\
\mathrm{m}^{-1} \times 10^{-6}\end{array}$ & $\begin{array}{c}\text { Maximal Growth Rate } \\
\text { day-1 }\end{array}$ \\
\hline SERI 3 & 0.92 & 0.48 \\
SERI 5a & 5.80 & 0.86 \\
SERI 5b & 3.60 & 0.66 \\
SERI 6 & 1.60 & 1.10 \\
SERI 7 & 1.22 & 0.71 \\
SERI 8 & 0.70 & 0.83 \\
SERI 9 & 1.20 & 0.50 \\
\hline
\end{tabular}

Cells grown without shaking at $35^{\circ} \mathrm{C}$, a $16 / 8$ light/dark cycle and $100 \mu \mathrm{E} \mathrm{m} \mathrm{m}^{-1}$ $\mathrm{sec}^{-1}$. SERI Type I medium, 25 mmhos $\mathrm{cm}^{-1}$.

Fluorometric Determination of Lipid Using the Dye Nile Red

The majority of the important results obtained with the fluorophore Nile Red have been included in the Appendix, an article submitted to the Journal of Microbiological Methods. However, two preliminary experiments not mentioned in that report are included here since they illustrate certain points of interest to the Aquatic Species Program. The results in Table 4 were obtained early in the project and demonstrate clearly that fluorescence per cell and the number of cells fluorescing increase as the culture passes from early to late stationary phase. This can be observed microscopically, but it was these results that alerted us to the quantitative information available through flow cytometry. Note also that the coefficient of variation of the relative fluorescence per cell decreases with time as cells became more uniformly fluorescent. Figure 1 was made using fluorescence data from early stationary phase cells. It can be seen that only one fluorescent population exists here, but there is a wide variation in fluorescence (and thus lipid) per cell. The larger cells can be seen to be more fluorescent. 
Table 4. Growth of A. coffeaeformis and Nile Red staining.

\begin{tabular}{ccccc}
\hline $\begin{array}{c}\text { Culture Age } \\
\text { (days) }\end{array}$ & $\begin{array}{c}\text { Relative } \\
\text { Fluorescence } \\
\text { per CeIl }( \pm \mathrm{CV})\end{array}$ & $\begin{array}{c}\text { Cells } \\
\text { Fluorescing } \\
(\%)\end{array}$ & $\begin{array}{c}\text { Cells/ml } \\
\times 10^{-5}\end{array}$ & $\begin{array}{c}\text { Relative } \\
\text { Fluorescence } \\
\text { per ml Culture }\end{array}$ \\
\hline 7 & $79.1( \pm 57 \%)$ & 63 & 0.729 & 36.3 \\
8 & $165.5( \pm 29 \%)$ & 90 & 0.859 & 127.9 \\
10 & $197.6( \pm 25 \%)$ & 92 & 0.828 & 150.5 \\
13 & $183.0( \pm 38 \%)$ & 99 & 0.726 & 131.5 \\
\hline
\end{tabular}

${ }^{1} \mathrm{CV}=$ coefficient of variation of mean fluorescence per cell from FACS. Acoffeaeformis was grown in ASP-2 medium with $0.25 \mathrm{mM}$ Ca until stationary phase ( 7 days). Cells were stained with Nile red $\left(10 \mu \mathrm{g} \mathrm{m1^{-1 }}\right)$ and examined after 5 min. Data was calculated using the LACEL-DISP4 program.

${ }^{2}$ (Cells mI-1 $\left.\times 10^{-6}\right) \times(\%$ cells fluorescing) $\times$ (fluorescence cell-1) $\times 0.01$ is proportional to lipid stained $\mathrm{ml}^{-1}$ culture. 
CORRELATION BETWEEN CELL SIZE

AND CELLULAR FLUORESCENCE

FOR A. coffeaeformis


\section{RELATIONSHIP OF NILE RED FLUORESCENCE AND CELL SIZE FOR A. coffeaeformis}

Figure 1. The fluorescence of Individual Nile Red stained cells was examined as a function of their size. Forward scattering of light by the cells is proportioned to their size. The forward scatter and fluorescence signals are automatically accumulated by the computer interfaced to the FACS. In 3(a) contour lines are drawn where cells have similar fluorescence and forward light-scattering properties. The contours represent $5,25,45,65$ and 85 events. Figure $3 b$ is a three-dimensional plot of the same data. 


\section{Discussion}

We will discuss the results by Task.

Task I: Collection and Isolation of Strains

Growth and Isolation of Strains. Only six of the 18 strains from our culture collection grew well at $35^{\circ} \mathrm{C}$. All of these strains had been isolated at $28^{\circ} \mathrm{C}$, nevertheless a temperature only $7^{\circ} \mathrm{C}$ higher was sufficiently stressful as to prevent reasonable growth. Thirty-five degrees is close to the highest temperature recorded for diatom growth under defined conditions $\left(42^{\circ} \mathrm{C}\right)(12)$, although living (but not necessarily viable) cells have been seen at $50^{\circ} \mathrm{C}$. The organism studied by Fairchild and Sheridan (12) was a species of Achnanthes and was isolated from a hot spring. It seemed a reasonable approach therefore to seek thermotolerant species for the biofuels program in thermally active environments.

The organisms described in this report are not extraordinary in their physiological attributes as far as we know, i.e., growth at 0.5-2 doublings per day and lipid contents of $9-57 \%$. There may be good reasons why algal cells in general may not contain more than approximately $60 \%$ of their dry weight as lipid. Lipid is less dense than water. A majority of the internal space in an algal cell is occupied by the chloroplast(s), so only a small fraction of the cell can be taken up by lipid. A second reason may be a direct result of the buoyancy of 1ipid. Cells with extraordinary amounts of lipid are likely to float, thus be far more susceptible to photo-damage than cells in the water column. Growth in SERI type II was never obtained, and poorer growth was recorded frequently in SERI type I medium than the artificial seawater medium, even for the non-marine species. These media may well represent southwestern desert groundwaters but in our hands they are less than ideal for algal growth. Both SERI types I and II were supplemented with bicarbonate, trace metals, phosphate, silicate, nitrate and vitamins before use.

We used the Nile Red staining method to screen collected algal inoculum on the assumption that this would be nutrient limited and therefore demonstrate lipid accumulation. Since it was always easier to collect more material and discard that in wich the algal cells did not stain with Nile Red, this was the policy we followed. This approach was followed also in initial enrichments, i.e., mixed cultures in which the algal cells did not fluoresce after Nile Red staining were discarded. We believe that this was a more efficient procedure than to test for lipid only after a culture has been made axenic (see below).

Task II: Determination of Lipid Content of Ten Algal Strains

The average lipid content of the cells mentioned in Table 2 was $29 \%$, i.e., about the same as the average reported for specially-selected, high yielding strains ( $31 \%$ ) by Benemann and Tillett (13). The figure of $29 \%$ average value was somewhat higher than that calculated from the data of Weissman and Goebel (i.e., 24\%) (14) or Tadros (15.9\%) (15). The strains on which Tadros reported, for Instance, were cultured and then analyzed for lipid. Here we report results from strains prescreened for lipid content before isolation into axenic culture. Thus it seems, from these rather small samples, that selection of natural inocula on the basis of Nile Red staining does improve the degree of success in culturing high lipid yielding strains from nature. 
We were somewhat disappointed, however, that in spite of the overall success of the procedure, it did allow the selection of some poor performers (10-20\% lipid) and only two high ylelding strains. It appears, therefore, that other environmental factors, unknown at the time of sample collection, may be influencing lipid synthesis in nature.

In spite of the fact that the overall level of lipid in these cultures was moderately high, only one grew at a rate much higher than one doubling per day (SERI 13). Thus, although these organisms may be useful in delineating pathways of lipid synthesis and control mechanisms, they cannot be recommended for large scale trials.

Task III: Development of Flow Cytometry and Other Fluorescence Techniques to Determine Lipid Content of Algal Cells

Flow Cytometry and Nile Red Staining. Our results indicate that by using the fluorescence of Nile Red stained cells, it is possible to assess the neutral lipid content of a population of $A$. coffeaeformis using a sample of about $10^{6}$ cells (Appendix). Nile Red stains the whole cell but only the non-polar reglons of a cell allow it to fluoresce. It does therefore stain spectfically the lipid inclusions in diatoms and other algae. Besides being a fluorophore of use in flow cytometry, it is also, in our opinion, the stain of choice for microscopy using an epifluorescence system. It is posstble to $f i x$ cells after staining (but not the reverse), making the method potentially suitable as a field procedure or in food-chain research. Since Nile Red itself does not kill algal cells, it is possible also to sort cells in a flow cytometer for further experimentation, if the fading problem seen after 10 min. In unfixed cells can be solved. Plant protoplasts have been separated on the basis of their fluorescein isothiocyanate staining (16), so we see no reason why the daughter cells of algal fusion experiments could not be separated from one another. For example, it is possible to select high lipid producing strains from wild-type cells. We have noticed in the green alga Chlorella Chlor-1 that even at late stationary phase, many cells possess no fluorescent Iipid droplets, whereas others contain very large amounts (see Fig. 5, Appendix). We are investigating this phenomenon using flow cytometry.

Use of Other Instruments to Measure Nile Red Fluorescence. As demonstrated in the Appendix, the considerable cost of a flow cytometer is not a handicap to using the Nile Red method. A spectrofluorometer was particularly convenient to use, especially in developing the method. Its use, for instance, allowed us to select appropriate filters to discriminate between Nile Red and chlorophyll fluorescence. This has been a problem for some workers, especially in Antarctica where the measurement of 1ipid production of under-ice diatoms has been attempted using the Nile Red method (Dr. A.

Palmisano, N.A.S.A., personal communication). The protocol developed in our laboratory has been supplied to $\mathrm{Dr}$. Palmisano and $\mathrm{Dr}$. D. C. White (Institute of Applied Microbiology, University of Tennessee) for use in their coming N.S.F. Antarctic Austral Summer Program (1987-88). In addition to this, the method has been distributed by SERI to all investigators in the Aquatic Species Program and is also used for in-house SERI research. Although we proposed originally to investigate the use of other non-polar fluorophores, Nile Red was so successful that we believed that this approach was unnecessary. Rather, we concentrated on developing our existing method.

It is important to realize that Nile Red in aqueous milieu stains the whole cell but only the non-polar regions of the cell fluoresce at the yellow 
wavelengths. We have shown that this fluorescence in diatoms arises primarily from the neutral triglyceride fraction of the cell (Appendix). Because of the small sample size required for the method, multiple analyses of comparatively small culture volumes were facilitated. This allowed us to show that neither nitrate or silicate limitation in Amphora coffeaeformis was responsible for the onset of neutral lipid accumulation. Similarly, the dependence of lipid accumulation on a medium $\mathrm{pH}$ shift, and again not on nitrate utilization, was also facilitated by the use of a method for the determination of neutral lipid that required only small samples (17).

Task IV: Development of a Radiotracer Assay for Lipid Production

This methodology was proposed as an alternative to the fluorescence method if that method was less than completely successful. We belleve that the results in the Appendix and the above discussion support our dectsion not to carry out this task. This was discussed with Program Directors at SERI.

$\underline{\text { References }}$

1. Shifrin, N. A. and Chisholm, S. W. (1981) Phytoplankton 1ipids: interspecific difference and effects of nitrate, silicate and light-dark cycles. J. Phycol. 17I:374-384.

2. Cooksey, K. E. (1972) Metabolism of organic acids by a marine pennate diatom. Plant Physiol. 50:1-6.

3. Cooksey, K. E. (1974) Acetate metabolism by whole cells of Phaeodactylum tricornutum. J. Phycol. 10:253-257.

4. Cooksey, R. E. and Chansang, H. (1976) Isolation and physiological studies of three strains of Amphora (Bacillariophyceae). J. Phycol. $12: 455-460$.

5. Barclay, B., Nagle, N., Terry, $K$ and Roessler, P. (1985) Collecting and screening microalgae for shallow, inland saline habitats. SERI Aquatic Species Program Review Proceedings. April 1985, pp. 52-67.

6. McLachlan, J. (1973) Growth media - marine. In: Stein, J. R. (ed.). Handbook of Phycological Methods: Culture Methods and Growth Measurements. Cambridge Univ. Press, London, pp. 25-51.

7. Bligh, E. G. and Dyer, W. J. (1959) A rapid method of total lipid extraction and purification. Can. J. Biochem. Physio1. 37:911-917.

8. Ben-Amotz, A. (1985) Development of an outdoor raceway capable of yielding ofl-rich halotolerant microalgae. SERI Aquatic Species Program Review Proceedings, April 1985, pp. 230-243.

9. Cooksey, K. E. (1981) A requirement for calcium in adhesion of a fouling diatom to glass. Appl. Env. Microbiol. 41:1378-1382.

10. Environmental Protection Agency (1983) Methods for chemical analysis of water and wastewater. U.S.E.P.A. Environmental Monitoring \& Support Laboratory, Cincinnati, Ohio. Document EPA 600/4-79-020 Mar. 1983. 
11. Brock, T. D. (1978) Thermophilic Microorganisms and Life at High Temperatures. Springer, N.Y., p. 465.

12. Falrchild, E., and R. P. Sheridan (1974) A physiological investigation of the hot spring diatom, Achnanthes exigua GRUN. J. Phycol. 10:1-4.

13. Benemann, J. R. and Tillett, D. M. (1986) The effects of fluctuating environments on the selection of high-yielding microalgae. SERI Aquatic Species Program, Ann. Report, February 1986, Pp. 285-299.

14. Weissman, J. C. and Goebel, R. P. (1986) Factors affecting the photosynthetic yield of microalgae. SERI Aquatic Species Program, Ann.

Report, February 1986, pp. 139-168.

15. Tadros, M. G. (1986) Screening and characterizing oleaginous algae microalgal species from the Southeastern United States. SERI Aquatic Species Program, Ann. Report, February 1986, pp. 67-89.

16. Galbratth, D. W., Alfonso, L. L, and Harkins, K. R. (1984) Flow sorting and culture of protoplasts. Plant Cell Reports. 3:151-155.

17. Guckert, J. D. and Cooksey, K. E. (1987) Monthly report to SERI. May 1987, Contract XK-5-05073-1.

Acknowledgements

The Principal Investigator acknowledges the contributions made to this research by L. Priscu, D. Berglund, P. R. Callis, S. A. Williams, J. B. Guckert, and espectally B. Cooksey, who provided all the marine strains used. 
Publications and Presentations Resulting from Contract XK-4-04136-04

1. Annual Meeting of the Phycological Society of America and Society for Limnology and Oceanography, Rhode Island, June 1986 (with D. Berglund, B. Cooksey and L. Priscu). Lipid Synthesis and Staining by Nile Red in an Oleaginous Marine Alga: Poster.

2. Seventh International Plant Lipid Symposium, Davis, California (with P. R. Callis and S. A. Williams). Nile Red: A Fluorophore Useful in Assessing the Relative Lipid Content of Single Cells: Poster.

3. Nile Red: A Fluorophore Useful in Assessing the Relative Lipid Content of Single Cells, in Plant Liplds: Blochemistry, Structure and Function. (Eds. P. K. Stumpf, J. A. Mudd and W. D. Nes). 'Plenum Press, N.Y., in press (with P. R. Callis and S. A. Williams).

4. Fluorometric Determination of the Neutral Lipid Content of Microalgal Cells Using Nile Red. J. Microbiological Methods (accepted) (with J. A. Guckert, S. A. Williams and P. R. Callis). 
Fluorometric Determination of the Neutral Lipid Content of Microalgal Cells Using Nile Red

Keith E. Cooksey, ${ }^{1}$ James B. Guckert, ${ }^{1}$

Scott A. Williams, ${ }^{2}$ and Patrik R. Callis ${ }^{2}$

Departments of Microbiology ${ }^{1}$ and Chemistry ${ }^{2}$

Montana State University, Bozeman, Montana 59717 (U.S.A.)

Correspondence addressed to: R. E. Cooksey 
Summary

The fluorophore Nile Red (9-diethylamino-5H-benzo[ $\alpha]$ phenoxazine-5-one) has been used to determine neutral lipid in microalgal cells. Cellular fluorescence of stained cells and gravimetrically- or chromatographicallydetermined lipid were linearly correlated when Nile Red was excited at 488-525 nm and the fluorescent emission measured at 570-600 nm. Nile Red is a vital stain which allowed flow cytometric sorting of live microalgal populations based on their lipid content.

Key words: Nile Red, microalgae, neutral lipid, flow cytometry. 
Introduction

Research concerning the posstbility of commercial production of Iipid by microorganisms has been stimulated in the last decade by the realization that the world's supply of crude oil is not everlasting. Several types of organisms have been proposed for the purpose of producing lipid, and each has its advantages. The particular advantages in the use of phototrophic microorganisms are that the source of energy and reducing power is the sun, and the carbon requirement of the cell can be met by carbon dioxide. Whatever the kind of microbial cell chosen for the 1ipid production process, it is probable that no wild-type organism will produce 1ipid in high enough yield for the process to be costeffective. It will be necessary therefore to select, or produce by genetic manfpulation, high-yielding strains. To do this successfully it is necessary to rapidly screen cellular lipid content in small samples of organisms and to be able to select suitably active cells on the same basis. It would be advantageous if the method discriminated between polar and non-polar lipids since only the non-polar product is commercially desirable as a fuel fraction [1]. These constraints suggest that a suitable method should be based on lipid staining with a vital dye, rather than a procedure dependent on 1ipid extraction. Chromatographic techniques, especially when combined with mass spectrometry, provide sensitivity and specificity in lipid analysis but do not overcome the need for an extraction step. Such techniques are also expensive of capital equipment and time. At least two staining methods have been proposed previously. Evans et al. [2] have described a semiquantitative 
procedure for staining with Sudan Black B, oleaginous yeast colonies on agar plates. Several groups of Russian workers have described lipid analyses based on the use of fluorescent probes. Pomoshnikova et a1. [4] have used the fluorescent stains 1,8-naphthoylene-1'-2' benzimidazole and its methoxy-substituted derivative to determine the lipid content of yeast and mycelial fungi. In later work Pomoshnikova et al. [3] used the fluorescent dye luminor 490PT to investigate the dynamics of 1ipid formation in fungal mycelia. Neither of these dyes appear to be readily commercially available. More pertinent to our research is the paper by Tertov et al. [5] who used a flow cytometer (Becton-Dickinson FACS II) to determine total intracellular lipid in mammalian tissue-culture cells using a perlenoyl labelled-triglyceride as a lipid probe. A linear relationship between fluorescence and lipid content of cells was found. Disadvantages of the method are (a) the probe must be synthesized, (b) staining takes several hours, (c) not all cells take up triglycerides, and (d) washing is needed to remove unbound fluorophore.

A series of papers from Greenspan, Mayer and Fowler $[6,7,8]$ led us to try the commercially avallable dye Nile Red in our search for a neutral lipid specific fluorophore [9] that could also be used as a vital stain. This paper describes a simple staining method for microalgal cells and its use in lipid determination. An abstract of parts of this paper has been published previously [10]. 
Materials and Methods

Growth of Algal Cells

Amphora coffeaeformis, Navicula sp. and Tropidoneis sp. were grown on the ASP-2 medium of Provasoli et al. [11] modified to contain $0.25 \mathrm{mM}$ $\mathrm{Ca}^{2+}$ [12]. Chlore11a sp. Chlor-1 (Solar Energy Research Institute, Golden, CO, USA, 80401) was grown on Bold's basal medium [13]. Cel1 concentrations were determined by using a hemocytometer. Cultures were incubated at $28-30^{\circ} \mathrm{C}$ and $100 \mu$ Einsteins $\mathrm{m}^{-2} \mathrm{sec}^{-1}$.

\section{Staining of Algal Cells}

Nile Red solution in acetone $\left(250 \mu \mathrm{g} \mathrm{mI}{ }^{-1}\right)$ and acetone were added to a suspension of cells in growth medium such that the final concentrations were $1 \mu \mathrm{g} \mathrm{m} 1^{-1}$ and $0.04 \%(\mathrm{v} / \mathrm{v})$ respectively. The mixture was vigorously agitated on a vortex mixer. Samples of this suspension were used immediately (or after $30 \mathrm{sec}$ ) for fluorescence microscopy, fluorometry or flow cytometry. Nile Red (9-diethylamino-5H-benzo[ $\alpha$ ]phenoxazine-5-one) was obtained from Molecular Probes, Junction City, OR 97748 or Kodak, Rochester, NY 14650 .

\section{Microscopy}

Photographs were taken with a Nikon Optiphot microscope using a 450-490 nm excitation filter, a $510 \mathrm{~nm}$ dichroic mirror and a $520 \mathrm{~nm}$ barrier filter. Ektachrome film (160 ASA, tungsten) set at ASA 80 was used. Color slide positives were used to make black and white internegatives for Fig. 5 . 
Flow Cytometry

A Becton-Dickinson FACS 440 flow cytometer was used. Diluent sheath fluid contained $308 \mathrm{mM} \mathrm{NaCl}, 20.2 \mathrm{mM} \mathrm{MgSO}_{4}, 8.1 \mathrm{mM} \mathrm{KCl}, 0.25 \mathrm{mM} \mathrm{CaCl}_{2}$, and $8.3 \mathrm{mM}$ Tris-HC1, $\mathrm{pH} 7.6$. The analytical aperture was set at $70 \mu \mathrm{m}$. Stained cells were excited at $488 \mathrm{~nm}$ and the emission recorded at $575 \pm 15 \mathrm{~nm}$ in conjunction with a $560 \mathrm{~nm}$ dichroic mirror. Results were collected as number of events versus the logarithm of the fluorescence intensity. Instrumental alignments were made daily and were based on the fluorescence of $2.8 \mu \mathrm{m}$ Nile Red-stained monodisperse latex particles (a gift of Dr. C. J. Wang, Pandex Laboratories, Mundelein, IL 60060). Fluorescence $\mathrm{m}^{-1}$ culture was calculated from cells $\mathrm{m}^{-1} \times \%$ of fluorescent cells $\times$ average fluorescence $\operatorname{cell}^{-1} \times 10^{-8}$.

\section{Spectrofluorometry}

In most experiments, the fluorescent properties of stained and unstained cells were measured using a Spex Fluorolog model F211 spectrofluorometer equipped with a $150 \mathrm{~W}$ Xeron lamp. Real time data acquisition and manipulation was performed using a Datamate microprocessor interface. Stained cell (2.5 ml) fluorescence was measured as a function of time for 800 seconds using a $1 \mathrm{sec}$ integration time per point. Wavelengths of excitation and emission were $525 \mathrm{~nm}$ and $580 \mathrm{~nm}$ respectively. Relative fluorescence in arbitrary units was measured $30 \mathrm{sec}$ after dye introduction, and this sample was re-mixed at intervals during time course measurements. Emission profiles were generated from 500 to $700 \mathrm{~nm}$ using $525 \mathrm{~nm}$ excitation and a $0.5 \mathrm{sec} / \mathrm{nm}$ integration time. In both the time course 
and emission measurements a bandpass of $4.5 \mathrm{~nm}$ on the emission and 2.25 $\mathrm{nm}$ on the excitation monochromotor was utilized. In experiments described in Tables 3-5, a Turner model 10 fluorometer with a $480 \pm 10 \mathrm{~nm}$ excitation filter and a $580 \pm 9.8 \mathrm{~nm}$ bandpass emission filter was used. This fluorometer was standardized using a suspension of monodisperse latex particles (Pandex Laboratories).

\section{Time-Course Experiments}

A series of $500 \mathrm{ml}$ cultures of A. coffeaeformis in $2.8 \mathrm{~L}$ Fernbach flasks were examined daily for cell number and Nile Red fluorescence. Based on these parameters, some of the flasks were harvested at early ( 5 days), mid ( 9 days) and late stationary phase ( 12 days). The contents of four flasks were pooled for the five day sample, two for the nine day sample, and for day 12, two flasks were analyzed independently. Cells were collected by centrifugation $\left(3000 \mathrm{xg}, 15 \mathrm{~min} ., 25^{\circ} \mathrm{C}\right)$ and the supernatent liquid saved for nitrate and silicate analysis. After wet weight determination, cells were lyophilized. Dry weight determinations were made on the lyophilized samples.

\section{Lipid Extraction}

In the experiments reported in Figure 4, extractions were made on wet-cell pellets by the method of Bligh and Dyer [14]. Results were calculated per ml of original culture. For other experiments, dried cell pellets were gently ground to break up large clumps, and dry weight determinations were made. The dry weights of samples for extraction ranged from 42-97 $\mathrm{mg}$. The pooled 5 day sample was split into two, 
approximately $60 \mathrm{mg}$ samples, so that the reproducibility of gravimetric and gas chromatographic lipid analyses could be found. All samples, along with procedural blanks, were randomly assigned to sequentially numbered separatory funnels such that the samples were blindly coded. The samples were then processed in a random order by processing them in this sequence.

A Bligh and Dyer [14] lipid extraction was also used for the lyophilized samples but in these cases as modified by White et al. [15]. The initial single phase was $37.5 \mathrm{~m} 1$ methanol: $18.75 \mathrm{ml}$ chloroform: $15.0 \mathrm{ml} 50 \mathrm{mM}$ phosphate buffer $(\mathrm{pH} \mathrm{7.4)}$. The cells were extracted for 19 hours before $18.75 \mathrm{ml}$ each of chloroform and distilled water were added to form 2 phases. The phases were allowed to separate for $24 \mathrm{hr}$. before the lower organic phase was removed and filtered through. Whatman $2 \mathrm{~V}$ filter paper into a round-bottom flask for drying.

\section{Total Lipid Gravimetric Determination}

The dried total extracted 1ipid was transferred from round-bottom flasks into previously tared test tubes fitted with teflon-lined screw caps and the solvent evaporated in a water bath $\left(<37^{\circ} \mathrm{C}\right)$ under a stream of dry nitrogen gas. This dried residue was defined as the total extracted lipid for all extraction procedures. The weight of this residue was recorded for a gravimetric estimate of total lipid yield.

\section{Silicic Acid Column Chromatography}

The total extracted Iipid was separated into three general classes by silicic acid column chromatography (SAC) [16]. Columns were 
disposable, large volume, glass pasteur pipets prepared with the approximate ratios of 50:1 stationary phase: 1fpid (dry weight) and 6.5:1 stationary phase column bed height to cross-sectional area. The stationary phase was Biosil A (100-200 mesh, B10-Rad Labs) activated at $120^{\circ} \mathrm{C}$ for at least $18 \mathrm{hr}$. The sample was loaded onto the column in a minimal volume of chloroform and a series of mobile phases of increasing polarity was used to separate the lipid classes: neutral 11pids in $10 \mathrm{ml}$ chloroform, glycolipids in $10 \mathrm{ml}$ acetone, and polar 1ipids in $10 \mathrm{ml}$ methanol. The fractions were collected in previously tared test tubes fitted with teflon-lined screw caps and dried under a stream of nitrogen, as before. Gravimetric estimates of lipid class yields were made as described for total lipid yield.

\section{Mild Alkaline Methanolysis}

This procedure will not methylate free fatty acids, but transesterification of fatty acids esterified to glycerol backbones is complete in just 15 min at $37^{\circ} \mathrm{C}[17]$. The procedure (detailed in [18]) results in fatty acid methyl esters (FAME) from each of the lipid classes separated by SAC.

Separation and Quantification of FAME by Gas Chromatography (GC)

Dry FAME were dissolved in appropriate volumes of iso-octane which contained approximately $500 \mathrm{pmol} / \mu 1$ of FAME (either 19:0 or 20:0, Sigma Chemical Co.) as an internal standards. Samples $(1.0 \mu 1)$ were injected for separation on a Varian $3700 \mathrm{GC}$ (Sunnyvale, CA) using a 30 meter, polar, DB-225 fused silica capillary column (J\&W Scientific, Folsom, CA). 
A splitless injection system with injector temperature at $200^{\circ} \mathrm{C}$ was used. Helium was the carrier gas (Inear velocity $=35 \mathrm{~cm} / \mathrm{s}$ ). The temperature program used began at $130^{\circ} \mathrm{C}$ and rose at $2^{\circ} / \mathrm{min}$ to $200^{\circ} \mathrm{C}$ with a final isothermal period of $10 \mathrm{~min}$ (total analysis time $=45 \mathrm{~min}$ ). The GC was equipped with a flame ionization detector (flame: hydrogen/air at 30/300 $\mathrm{ml} / \mathrm{min}$, make-up gas: helium at $30 \mathrm{ml} / \mathrm{min}$, detector temperature $=210^{\circ} \mathrm{C}$ ). An equimolar response was assumed for all FAME in the range analyzed (14:0 to $24: 0)$. Peak areas were quantified by a programmable Waters Data Module M730 (Milford, MA). The area of each peak was compared to the internal injection standard area to determine the quantity of each separated FAME.

Data reported in this study are the total molar amount of FAME for each lipid class (gas chromatographic method, e.g. Table 3). GC peaks were identified by two methods. First, by co-elution or identical relative retention times with standards obtained from Supelco, Inc. (Bellefont, PA); Applied Science Laboratories, Inc. (State College, PA); Nu-Chek Prep (Elysian, MN); or previously identified laboratory standards. Second, GC/mass spectrometry (MS) was utilized to verify the FAME as previously described [18]. Samples were analyzed on a VG MM-16 GC/MS (Manchester, UK) fitted with a direct capillary inlet. The separation conditions were identical to those described above for GC. Mass spectrometer operating conditions were: electron multiplier voltage $=4000$ volts, transfer line temperature $=200^{\circ} \mathrm{C}$, source and analyzer temperature $=200^{\circ} \mathrm{C}$, calibration file tuned to per-fluoro-kerosene- $\mathrm{H}$ (PFK), and electron impact energy, $70 \mathrm{eV}$. 
Analytical Reproducibility of the Nile Red Method

So that the variability of the methods could be compared, five replicate $6 \mathrm{ml}$ samples of an Amphora culture in stationary phase were analyzed for cell concentration and Nile Red fluorescence. The coefficient of variation of this method was compared with those for gravimetric and GC lipid estimation.

\section{Analysis of Silicate and Nitrate}

The concentrations of nitrate ( $\mathrm{mg} \mathrm{N} 1^{-1}$ ) and silicon (total $\mathrm{SiO}_{2} \mathrm{mg}$ $1^{-1}$ ) were estimated by the cadmium reduction and silicomolybdate methods respectively, using commercially available test kits (Hach Inc., Loveland, C0).

\section{Statistical Analyses}

These were performed using a Honeywe11 level 66/DPS computer with a CP-6 operating system utilizing programs available in the MiniTab Software package. Correlations were calculated as Pearson's product-moment correlation coefficients [19].

Results and Discussion

Table 1 indicates that the Nile Red concentration needed to achieve maximal fluorescence in the flow cytometer was not critical. In fluorometric measurements it is sometimes necessary to wash stained cells by centrifugation to lower background fluorescence. With Nile Red, the fluorescence yield in polar environments is so low [7] that this step is 
not necessary. Fluorescence which developed rapidly in Amphora at $585 \mathrm{~nm}$ (Fig. 1) when stained cells were excited at $525 \mathrm{~nm}$, was stable for between 2-7 min. After that time, fading, but not settling of the stained cells, took place (Fig. 1). With other algae (data not shown here), the shape of this curve was different. It is necessary, therefore, to investigate the development of fluorescence with time for individual species. The time course of fluorescence development is probably related to the cellular permeability for Nile Red and whether the lipid is in small (Chlore11a) or large (Amphora) droplets within the cell. If sample numbers were kept within a manageable size or measurements were made individually, the length of this time window was not inconvenient. Formaldehyde-fixed cells did not stain (Fig. 2), however, cells could be fixed in such a solution $(5 \%)$ or ethanol $(70 \% \mathrm{v} / \mathrm{v})$ after staining. The fluorescence of stained, fixed and washed cells was stable for about $2 \mathrm{hr}$ (data not shown), however the inclusion of a washing step in a quantitative procedure was undesirable from the point of view of cell recovery. The fluorescence generated by intracellular lipid was linear (Figs. 3 and 4). In Fig. 3, cells of a Navicula sp. were grown until $\mathrm{NO}_{3}^{-}$in the medium was depleted and lipid synthesis in the cell was advanced. The fluorescence of various culture dilutions was measured using the spectrofluorometer. The relationship was Iinear with a correlation coefficient of $r=1.00$. In the experiments shown in Fig. 4, samples of a growing culture of A. coffeaeformis were taken over a period of 1-11 days. During this time cells accumulated lipid which was determined gravimetrically as total lipid. Parallel determination of the fluorescence of Nile Red-stained cells gave a linear relationship 
$(r=0.95)$. This data differs from that in Fig. 3 in that here fluorescence determinations were made by flow cytometer and the lipid content of the cells varied, rather than their concentration.

Although previous work by Greenspan, Mayer and Fowler $[5,6,7,8,9]$ led us to belleve that the increase in fluorescence of lipid-accumulating algal cells was due to the increased synthesis of neutral lipid, we had no proof that this was so in algae. Accordingly, a time-course experiment was performed wherein the fluorescence of Nile Red stained A. coffeaeformis was compared to the major lipid components of the culture during the time period that Nile Red-staining droplets began to be observed microscopically within the cell. The results of this experiment appear in Tables 3 and 4. During the 4 day period from day 5 to day 9, Nile Red fluorescence rose 21 fold, however, cell density rose less than 2 fold. Also over this period the neutral lipid fraction of the cell was the only lipid fraction to change materially. From day 9 to 12, there was no increase in cell number, but the Nile Red fluorescence rose approximately 2 fold. Once more the only lipid fraction to increase was the neutral lipid one. These relationships are correlated statistically in Table 4. Cellular Nile Red fluorescence is correlated most positively to the neutral lipid fraction of the cell. The neutral lipid fraction, as determined by GC analysis, represents the esterified fatty acid fraction of the cell, i.e., mostly triglycerides.

This method was developed, in part, for use in a screening program to discover and select high lipid-producing algae. However, another use In our laboratory is to define the point in time when neutral lipid accumulation is triggered. It is well accepted that the increase in 
total lipid of microalgal cultures becomes noticeable when cells can no longer divide because of nitrogen or, for diatoms, silicate-limitation [reviewed in 20,21]. Although the work of Shifrin and Chisholm [20] and Ben-Amotz et al. [21] confirmed earlier reports that these limitations did result in lipid accumulation, their experiments are not strictly comparable to those reported in Table 3. Whereas these workers measured total lipid [20] or neutral lipid [21] only after cells had experienced nutrient limitation for some time, we, because of the sensitivity of the Nile Red method, were able to measure cellular lipid during growth, when the cells were not obviously nutrient limited. Thus, it appears, at least in A. coffeaeformis, the onset of lipid accumulation takes place well before $\mathrm{NO}_{3}^{-}$or $\mathrm{Si}$ Iimftation is evident (Table 3, 1ines 4,5). Our confidence in such a conclusion is supported by the reproducibility of the Nile Red method. An experiment to compare the reproductbility of the three lipid determinations used here showed that the Nile Red procedure was as good as the gravimetric method commonly used for lipid determination [e.g., 20] and, as one would expect, was somewhat better than the GC analytical method, which required a considerably greater number of experimental manipulations.

The general applicability of the method, at least for algae, is shown in Fig. 5 and Table 2. All organisms showed an increased fluorescence and thus lipid content as they entered the stationary phase of growth. The method allowed comparisons of relative lipid contents of sma11 quantities of cells $\left(<5 \times 10^{6}\right)$. Since Nile Red does not kill algal cells, it was possible, using a flow cytometer in the "sort" mode, to select cells of above average lipid content for further study (data not shown). 
Where absolute lipid content of a population was required, it was necessary first to prepare a standard such as that depicted in Fig. 4. We see no reason why this method could not be applied to determine neutral 1ipid in other types of cells.

\section{Acknowledgments}

This research was supported by the Solar Energy Research Institute, Golden, CO, USA, contract number XK-4-04136-04 and XK-5-05073-1. We thank David Davies and Barbara Cooksey for technical help and methodological suggestions, respectively, and Deborah Bergland for flow cytometric measurements.

\section{References}

1 Ryan, T.W., III, Doge, L.G., and Callahan, T.J. (1984) The effects of vegetable oil properties on injection and combustion in two different diesel engines. J. Am. Oil Chem. Soc, 61, 1610-1619.

2 Evans, C.T., Ratledge, C. and Gilbert, S.C. (1985) A rapid screening method for lipid-accumulating yeast using a replica-printing technique. J. Microbiol. Meth. 4, 203-210.

3 Pomoshnikova, N.A., Medvedeva, G.A., Levchenko, M.N., Meise1, M.N., and Krasovitski1, B.M. (1981) Use of fluorescent techniques for detection and quantitative determination of lipids in cells of microorganisms. Microbiology (USSR Intern. Ed.) 50, 176-182.

4 Pomoshnikova, N.A., Korotkov, S.A. and Galanina, L.A. (1983) Use of fluorescent analysis for the study of Ifpid synthesis by mycelial fungi. Microbiology (USSR (Intern. Ed.) 52, 698-701. 
5 Tertov, V.V., Orekov, A.N., Rudchenko, S.A., Mukhin, D.N., Smirnov, V.N., Molotkovsky, Yu,G. and Bugelson, L.D. (1985) Determination of total intracellular lipid content by flow cytometry. Biochem. Biophys. Res. Comm. 128, 1196-1202.

6 Greenspan, P.E., Mayer, P. and Fowler, S.D. (1985) Nile Red: a selective fluorescent stain for intracellular lipid droplets. J. Cell Biol. 100, 965-973.

7 Greenspan, P. and Fowler, S.D. (1985) Spectrofluorometric studies of the lipid probe, Nile Red. J. Lipid Res. 26, 781-9.

8 Fowler, S.D. and Greenspan, P. (1985) Application of Nile Red fluorescent hydrophobic probe for the detection of neutral lipid deposits in tissue sections: Comparisons with 011 Red $0 . \mathrm{J}$. Histochem. Cyto. Chem. 33, 833-836.

9 Fowler, S.D., Brown, W.J. and Greenspan, P. (1986) Use of Nile Red for rapid qualitative analysis of lipids by thin-layer chromatography. Fed. Proc. 45, 1669.

10 Cooksey, K.E., Williams, S.A. and Callis, P.R. (1986) Nile Red: A fluorophore useful in assessing the relative lipid content of single ce11s. In: Biochemistry, Structure and Function of Plant Lipids (Stumpf, P.K., Mudd, B. and Nes, W.D., eds.), Plenum Press (In press).

11 Provasoli, L., McLaughlin, J.J.A. and Droop, M.R. (1957) The development of artificial media for marine algae. Arch. Mikrobiol. $25,392-428$.

12 Cooksey, K.E. and Chansang, H. (1976) Isolation and physiological studies on three isolates of Amphora (Bacillariophyceae). J. Phycol. $12,455-460$. 
13 Nichols, H.W. (1973) Growth media - freshwater. In: Handbook of Phycological Methods: Culture Methods and Growth Measurements (Stein, J.R., ed.), pp. 7-24, Cambridge University Press, London.

14 B1igh, E.G. and Dyer, W.J. (1959) A rapid method of lipid extraction and purification. Canad. J. Biochem. Physiol. 35, 911-917.

15 White, D.C., Davis, W.M., Nicke1s, J.S., King, J.D. and Robbie, R.J. (1979) Determination of sedimentary microbial biomass by extractable lipid phosphate. Oecologia (Ber1.) 40, 51-62.

16 Gehron, M.J. and White, D.C. (1983) Sensitive assay for phospholipid glycerol in environmental samples. J. Microbiol. Methods, 1, 23-32.

17 Christie, W.M. (1973) Lipid analysis: isolation, separation, identification and structural analysis of 1ipids. Pergamon Press, Oxford. 338 pp.

18 Guckert, J.B., Antworth, C.P., Nichols, P.D. and White, D.C. (1985) Phospholipid, ester-linked fatty acid profiles as reproducible assays for changes in prokaryotic community structure of estuarine sediments. FEMS Microbiol. Eco1. 31, 147-158.

19 Sokal, R.R. and Rohlf, F.J. (1981) Biometry, 2nd Ed., W.H. Freeman, San Francisco. 859 pp.

20 Shifrin, N.S. and Chisholm, S.W. (1981) Phytoplankton lipids: interspecific differences and effects of nitrate, silicate and light-dark cycles. J. Phyco1. 17, 374-384.

21 Ben-Amotz, A., Tornabene, T.G. and Thomas, W.H. (1985) Chemical profiles of selected species of microalgae with emphasis on 1ipids. J. Phycol. 21, 72-81. 
Legends to Figures

Fig. 1. Time-course of staining and fading of Nile Red-stained cells of A. coffeaeformis $\left(8.8 \times 10^{5} \mathrm{ml}^{-1}\right)$. Arrow indicates cuvette contents re-mixed. Zero time represents 30 s since dye was added to cell suspension. Excltation $525 \mathrm{~nm}$, emission $585 \mathrm{~nm}$.

Fig. 2. Relative fluorescence emfssion of Nile Red-stained, unstained and fixed cells of $\mathrm{A}_{\text {. coffeaeformis }}\left(8.3 \times 10^{5}\right.$ cells $\left.\mathrm{ml}^{-1}\right)$. Excitation at $525 \mathrm{~nm}$.

Fig. 3. Fluorescence of Navicula sp. 9D stained with Nile Red: spectrofluorometric data.

Fig. 4. Fluorescence of A. coffeaeformis stained with Nile Red: flow cytometer data. For detalls of calculation of fluorescence $\mathrm{ml}^{-1}$, see text. Total lipid determined gravimetrically. Circles and triangles represent independent experiments.

Fig. 5. Cells of Chlorella sp. Chlor-1 (Solar Energy Research Institute Culture Collection) in nitrogen sufficient (a) and nitrogen depleted (b) media. (c) Amphora sp. In nitrogen depleted media. Note that 1ipid accumulates on one side of the chloroplast only in this organism. 
TABLE 1

STAINING OF A. COFFEAEFORMIS WITH NILE RED

\begin{tabular}{ccc}
\hline $\begin{array}{c}\text { Concentration of Nile Red } \\
\left(\mu \mathrm{g} \mathrm{m}^{-1}\right)\end{array}$ & $\begin{array}{c}\text { Average fluorescence } \\
\text { per cell (arbitrary units) }\end{array}$ & $\begin{array}{c}\text { Cells fluorescent } \\
(\%)\end{array}$ \\
\hline 0.01 & 38.4 & 13.9 \\
0.10 & 44.8 & 28.3 \\
1.00 & 61.0 & 95.4 \\
10.00 & 62.9 & 92.8 \\
\hline
\end{tabular}


TABLE 2

FLUORESCENCE OF THREE DIATOM ISOLATES

\begin{tabular}{lcccc}
\hline & & \multicolumn{3}{c}{ Cell ml } \\
Organism & \multicolumn{2}{c}{ Relative fluorescence ${ }^{-1}$ after } & $\times 10^{-6}$ & $\mathrm{No}_{3}^{-}$used $^{\text {b }}$ \\
& 4 days & 8 days & 8 days & $\%$ \\
\hline Navicula sp. 6 & 179.1 & 340.7 & 2.66 & 99.4 \\
\hline Navicula sp. 9D & 159.4 & 387.7 & 2.55 & 99.0 \\
Tropidoneis sp. 17 & 29.8 & 67.7 & 0.42 & 99.6 \\
\hline
\end{tabular}

a See "Methods" for calculation.

$\mathrm{b}$ Initial nitrate concentration $=0.59 \mathrm{mM}$. 
TABLE 3

TIME-COURSE EXPERIMENT WITH A. COFFEAEFORMIS: ANALYSES

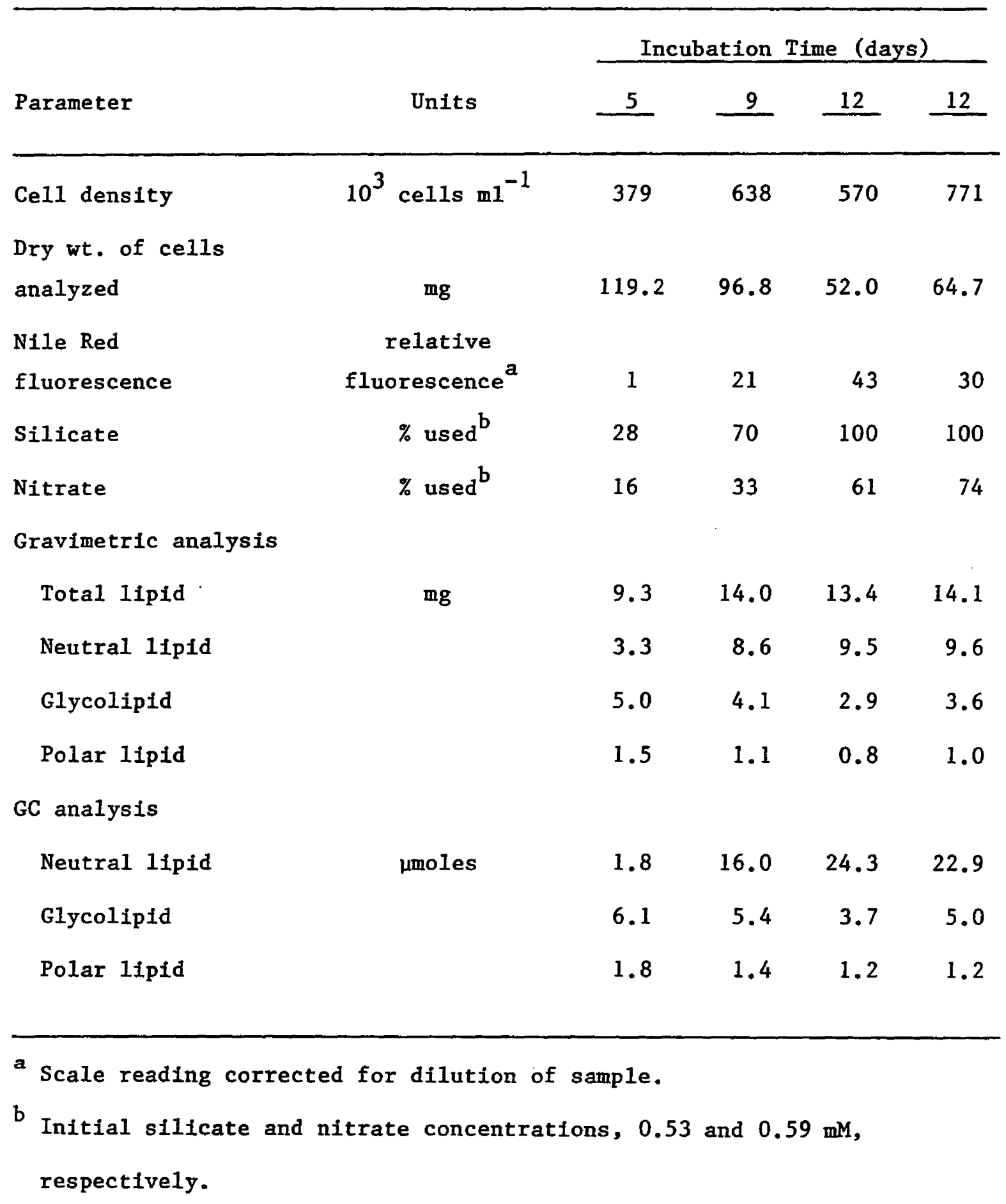


TABLE 4

CORRELATION OF NILE RED FLUORESCENCE AND LIPID CLASSES ESTIMATED

GRAVIMETRICALLY AND BY GAS CHROMATOGRAPHIC ANALYSES

Lipid Estimate

Coefficient $^{a}(r)$

Gravimetric Analysis (mg)

Total Iipid

0.79

Neutral lipid

0.91

Glycolipid

$-1.00$

Polar 1fpid

$-1.00$

Gas Chromatographic Analysis (umoles)

Neutral 1ipid

0.97

Glycolipid

$-0.96$

Polar Ilpid

$-0.95$

a Pearson's product-moment correlation. 







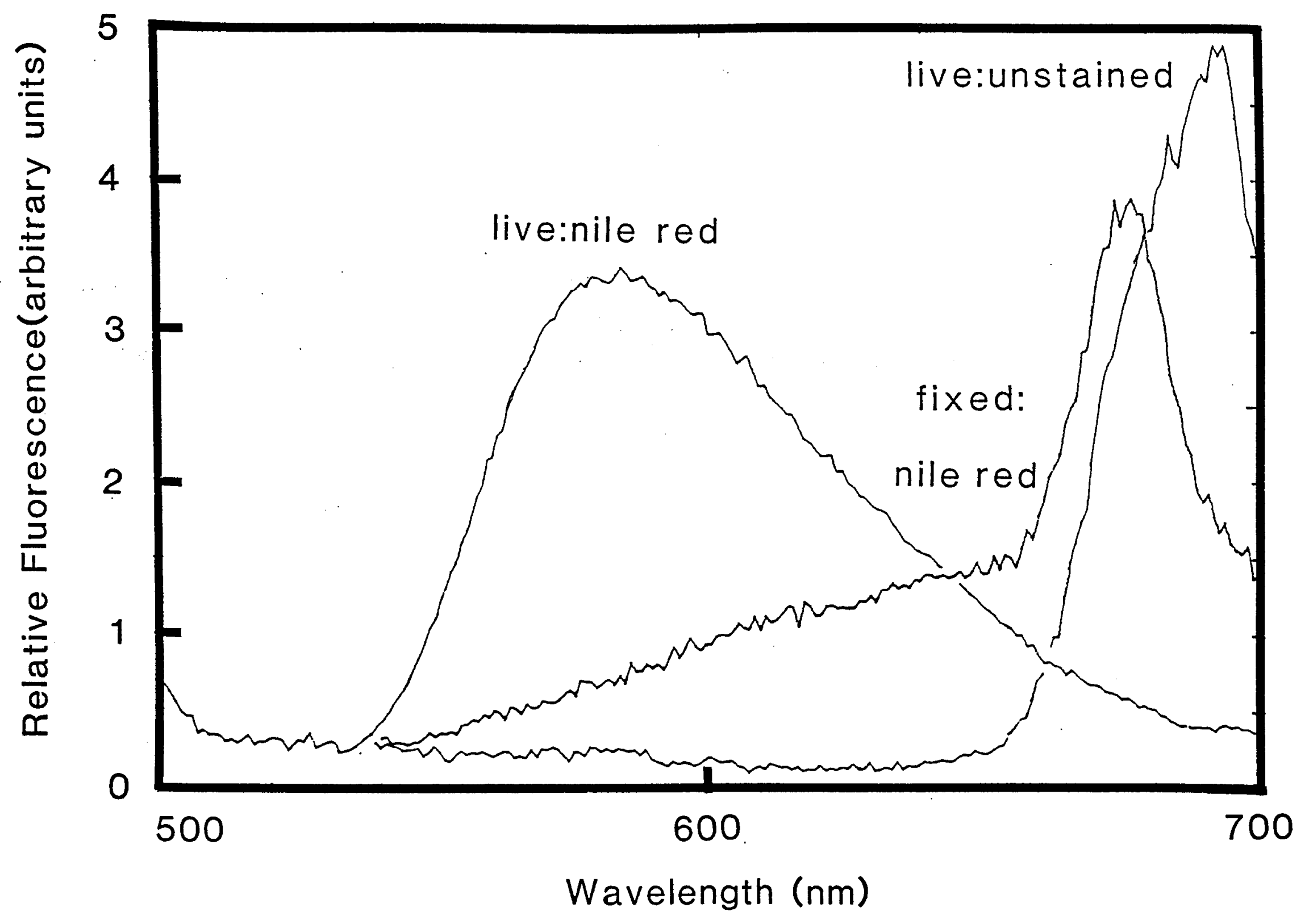




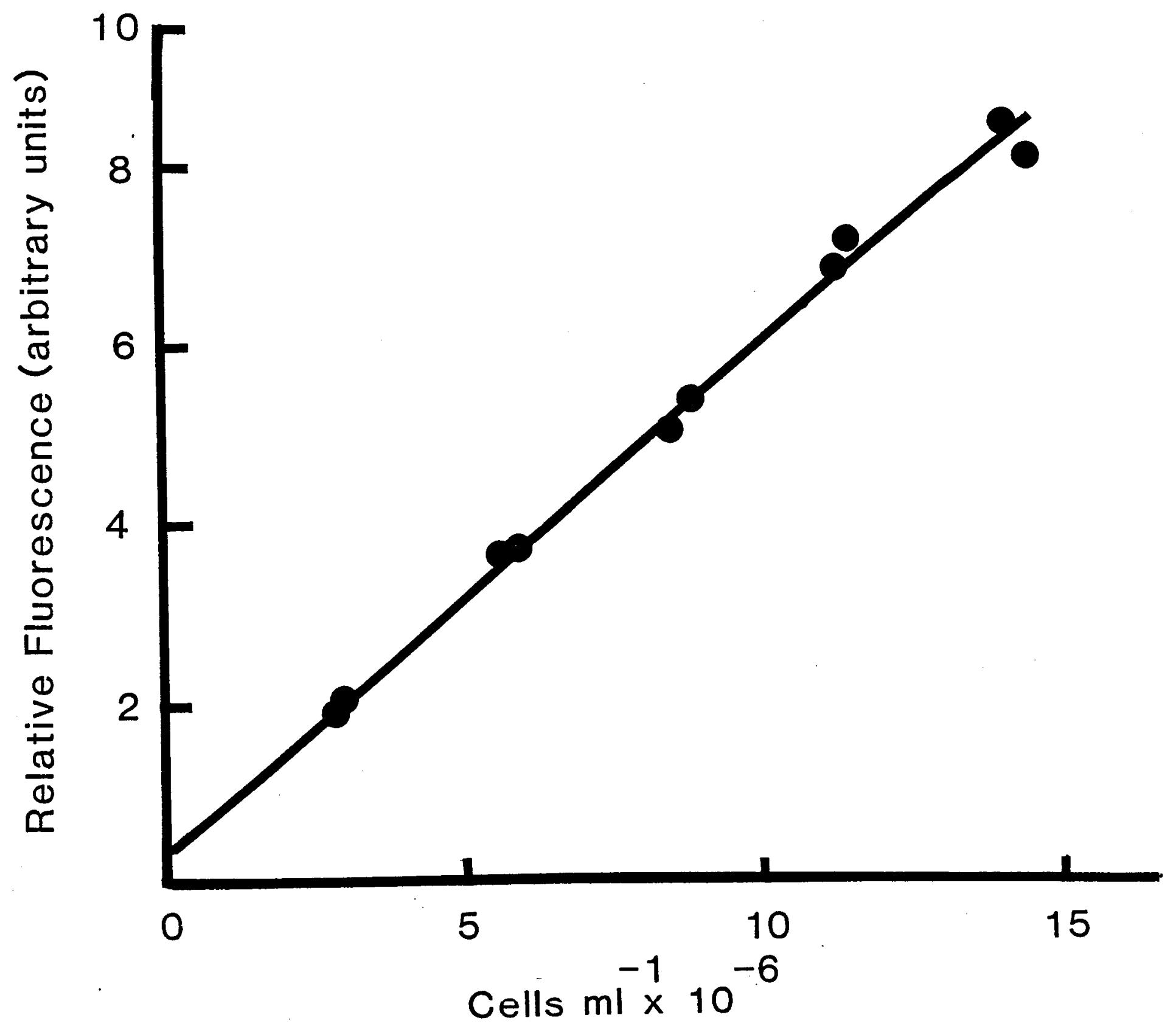



